\title{
Corona de Espinas 19:2-5
}

\author{
Crown of thorns
}

Olmedo Bula Villalobos

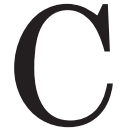
on una insólita parsimonia encendió su cigarrillo. El cerillo dejaba ver una flama, que danzaba espectacularmente ante sus ojos. Le era imposible, ni siquiera intentaba, dejar de ver el mágico destello que lo tenía atónito; disfrutaba cada bocanada sin perder detalle de la vista seductora y cálida de la lumbre de su cigarrillo. De pronto, una llamada lo sacó de su éxtasis. Altoparlante: -Urgente, urgente, todos los enfermeros diríjanse a la sala de emergencia, dos primíparas con traumatismo craneoencefálico severo, urgente-. Aquello era un verdadero pandemonio, sangre, gritos, llanto, agujas, adrenalina, decisiones y mucho estoicismo. Una vez más, Norman demostró su sapiencia y pericia como enfermero. Era el brazo derecho de los doctores, tomando decisiones que aseguraban el bienestar de aquellas desgraciadas. En definitiva, decisiones de vida o muerte.

La noche era joven y presagiaba una jornada intrascendente. Estaba regresando de la lavandería, cuando un grito desgarrador y violento sacudió todo su ser. -¡Fuego, fuego! ¡Se quema el hospital!-. Aquel conato de incendio pronto se transformó en un infierno de fuego, un monstruo de mil lenguas. El incendio amenazaba con devorar toda el ala sur de la edificación y arrebatar de forma espantosa la vida de pacientes y funcionarios que allí se encontraban. Consciente de aquel caos, Norman lideró las acciones para combatir ese demonio, gritaba y daba órdenes precisas. Con gran valentía y coraje, guió a los bomberos al punto exacto de origen de aquella desgracia. Su cara se iluminó con el resplandor de la llamarada. ¡Nadie lo podía creer! Los bomberos habían logrado extinguir aquella maldita deflagración de proporciones descomunales que por poco les cuesta la vida.

De la noche a la mañana, aquel puñado de hombres se convirtieron en héroes de todo un país. Norman trataba de no figurar en aquel sinnúmero de reconocimientos. Al fin de cuentas, era solo su trabajo, como él solía decir. 
Eran 22 vidas, sí, habían logrado sal- no lo dejaba destacarse. Absorto en su var 22 almas. Poco a poco, el hospital pensamiento, se dirigió a la lavanderetornó a su impasible rutina. Nor- ría, encendió un cerillo y se dijo a sí man también había vuelto a la coti- mismo: -Esta vez no puedo fallar-. dianeidad, ese absurdo día a día que 